\title{
Enantioselective catalytic lithiation using a chiral binaphthyl derivative as electron carrier
}

\author{
Regina Martínez, Isidro M. Pastor,* and Miguel Yus* \\ Departamento de Química Orgánica, Facultad de Ciencias and Instituto de Síntesis Orgánica \\ (ISO), Universidad de Alicante, Apdo. 99, 03080 Alicante, Spain \\ E-mail:ipastor@ua.es,yus@ua.es
}

\section{Dedicated to Prof. Rosa M. ${ }^{\text {a }}$ Claramunt on the occasion of her $65^{\text {th }}$ birthday}

\begin{abstract}
The lithiation, of the secondary chloride $\mathbf{2}$, catalyzed by binaphthyl derivatives, i.e. BINAM $\mathbf{4}$, BINOL 5, BINAP 6, H8-BINAP 7, Tol-BINAP 8, 2,2'-bis(pyrrolidin-1-yl)-1,1'-binaphthalene 9, and 2,2'-dimethyl-1,1'-binaphthalene 11, in the presence of different ketones has been studied, yielding the corresponding alcohol derivatives 3 and 12-16 in moderate to good yields. Binaphthyl derivative $\mathbf{1 1}$ has revealed to be very active as catalyst in the lithiation process at room temperature, and has allowed the preparation of the alcohol derivatives with enantioselectivities up to $50 \%$.
\end{abstract}

Keywords: Lithium metal; stereoselectivity; binaphthyl derivatives; arene catalyzed lithiation

\section{Introduction}

The formation of carbon-carbon bonds represents a key step in the synthesis of many organic products, and organometallic reagents have become a fundamental tool in order to accomplish this type of transformation. ${ }^{1-3}$ Organolithium compounds constitute a unique class of reagents due to their characteristic reactivity, the functionalized organolithiums and the polylithium synthons being of special interest in organic synthesis. ${ }^{4-15}$ Deprotonation and halogen/lithium exchange, employing commercially available organolithium reagents, are conventionally the main routes for the preparation of other organolithium reagents. Nevertheless, there are other alternative routes such as carbon-heteroatom bond cleavage, transmetallation and carbolithiation, which have become complementary processes in the preparation of organolithium intermediates. ${ }^{16-18}$

Considering the lithiation agent, two main methodologies can be employed. The first one consists in the use of another organolithium reagent, and the second is a reductive lithiation 
process by means of lithium. The latter has been extensively studied employing an arene or a diene as mediator. Thus, lithium metal in combination with a substoichiometric amount of an arene, as electron carrier, has become a very versatile methodology in the preparation of organolithium intermediates, ${ }^{19-23}$ as well as in the preparation of nanoparticles of different transition metals. ${ }^{24-27}$ Furthermore, the mechanism of this well-established methodology has been considered in different studies. ${ }^{28-30}$ Herein, the use of chiral arene compounds, such as binaphthyl derivatives, as electron shuttle agents in order to get a stereoselective reductive lithiation process has been studied.

\section{Results and Discussion}

The study has been carried out employing racemic 2-chloro-1-phenylpropane $\mathbf{2}$ as starting material. Compound $\mathbf{2}$ was easily prepared from the commercially available 1-phenylpropan-2-ol 1 with thionyl chloride (Scheme 1). First of all, we tested that the lithiation of 2 with lithium powder does not taken place in the absence of an electron carrier, a necessary condition in order to avoid the non-stereoselective uncatalyzed reaction. Therefore, treatment of chloride $\mathbf{2}$ with an excess of lithium, in the presence of the electrophile (i.e. pentan-3-one), at room temperature in dry THF did not produce the corresponding organolithium intermediate, and consequently the expected alcohol $\mathbf{3}$ was not obtained after hydrolysis. On the contrary, the reaction of $\mathbf{2}$ with an excess of lithium and a substoichiometric amount of 4,4'-di-tert-butylbiphenyl (DTBB, 20 $\mathrm{mol} \%$ ) in the presence of pentan-3-one, at room temperature in dry THF, gave the corresponding organolithium intermediate, which reacted with the carbonyl compound, and after hydrolysis the alcohol 3 was obtained in 74\% isolated yield (Scheme 2). Additionally, we tested the use of naphthalene as electron carrier under similar reaction conditions, and the final product was isolated in $45 \%$ yield.

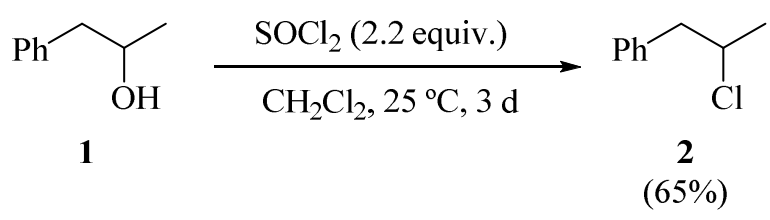

Scheme 1. Preparation of compound 2 by chlorination of alcohol 1.

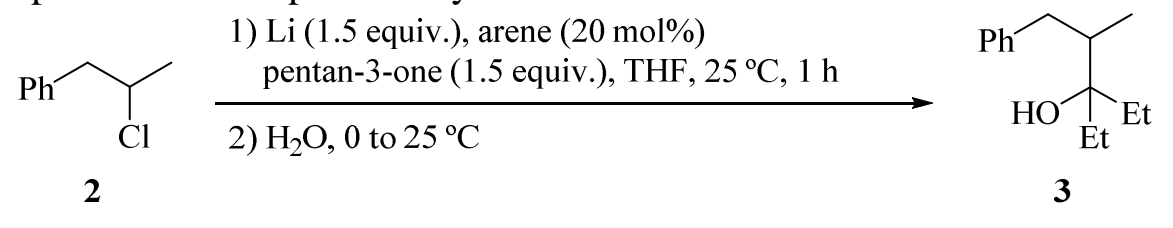

DTBB: $74 \%$

Naphthalene: $45 \%$

Scheme 2. Arene catalyzed lithiation of 2-chloro-1-phenylpropane 2 with lithium metal. 
Firstly, different commercially available enantioenriched binaphthyl derivatives, such as BINAM 4, BINOL 5 and BINAP 6, were tested as electron carriers in the lithiation reaction of compound 2, employing $20 \mathrm{~mol} \%$ of arene in combination with an excess (1.5 equiv.) of lithium powder. Thus, 2-chloro-1-phenylpropane was treated with lithium metal and a binaphthyl derivative 4-6 in THF at room temperature, and in the presence of pentan-3-one as electrophile (Table 1). The binaphthyl derivative 4 was not an effective catalyst for the lithiation reaction of chloride 2 (Table 1, entry 1). In sharp contrast, binaphthyl derivatives 5 and $\mathbf{6}$ were shown as active catalyst as DTBB producing, after hydrolysis, the expected alcohol $\mathbf{3}$ with similar isolated yields (73 and $72 \%$, respectively), although both catalysts produced the final alcohol almost as a racemic mixture (Table 1, entries 2 and 4). Taking into account the good activity shown by BINAP, we extended the study using other commercially available derivatives, such as $2,2^{\prime}$ bis(diphenylphospino)-5, 5',6,6',7,7',8,8'-octahydro-1,1'-binaphthalene 7 (H8-BINAP) and 2,2'bis(4-tolylphosphino)-1,1'-binaphthalene 8 (Tol-BINAP). Accordingly, as expected, the use of compound 7, which lacks naphthyl moities, resulted in loss of the activity as electron carrier, and the chlorinated starting material was recovered (Table 1, entry 5). On the other hand, the binaphthyl derivative $\mathbf{8}$ showed similar activity as BINAP (Table 1, entry 6), having no influence in the enantioselectivity of the process. Additionally, compound 9, which was prepared from BINAM by a reported procedure, ${ }^{31}$ proved to be slightly active as catalyst producing the expected alcohol $\mathbf{3}$ with a $19 \%$ yield (Table 1, entry 7).

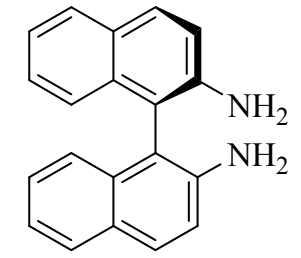

4

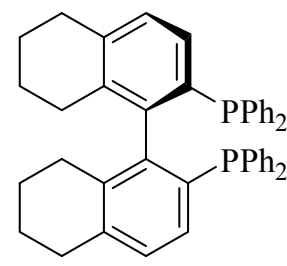

7<smiles>Oc1ccc2ccccc2c1-c1c(O)ccc2ccccc12</smiles>

5

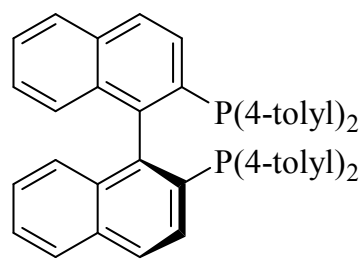

8<smiles>c1ccc(-c2ccc3ccccc3c2-c2ccc3ccccc3c2-c2ccccc2)cc1</smiles>

6

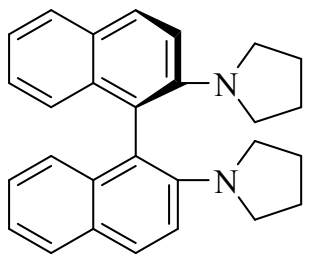

9

Figure 1. Functionalized-binaphthyl derivatives employed as electron carriers.

Subsequent attempts to improve the outcome of the reaction, employing the highly active BINOL and BINAP, were made by changing the solvent and the temperature. Thus, the lithiation of compound 2, in the presence of pentan-3-one, at $0{ }^{\circ} \mathrm{C}$ and employing the mixture lithium/BINOL 5 was tested in different apolar (i.e. hexane and toluene) and polar solvents (i.e. 
diethyl ether, dimethoxyethane, $t$-butyl methyl ether and 2-methyltetrahydrofuran), producing the expected alcohol 3 with significantly low yields (ranging from 20 to 38\%), with the exception of the 2-Me-THF for which the yield of product 3 was 70\% (Table 1, compare entries 3 and 8-13). Moreover, the reaction in 2-methyl-THF produced the final product with similar enantioselectivity to that obtained in THF (Table 1, entry 13). Performing the reaction at $-78{ }^{\circ} \mathrm{C}$ resulted in a remarkable reduction of the activity, and without significant change in the selectivity (Table 1, entries 14 and 15). Concerning BINAP, its activity as catalyst also lessened with the temperature, and without effect on the selectivity (Table 1, entries 16-18). As has been observed previously, THF is the solvent of choice when performing lithiation reactions with lithium metal in the presence of an arene as electron carrier. ${ }^{19-23}$

Table 1. Enantioselective lithiation with different chiral electron carriers ${ }^{\mathrm{a}}$

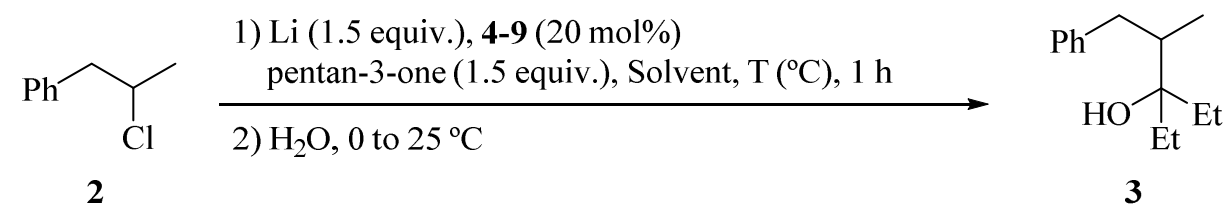

\begin{tabular}{ccccc}
\hline Entry & Arene & Solvent & T $\left({ }^{\circ} \mathrm{C}\right)$ & Yield (ee \%) $)^{\mathrm{b}}$ \\
\hline 1 & $\mathbf{4}$ & THF & 25 & n.r. $^{\mathrm{c}}$ \\
3 & $\mathbf{5}$ & THF & 25 & $73(<1)$ \\
4 & $\mathbf{5}$ & THF & 0 & $70(3)$ \\
5 & $\mathbf{6}$ & THF & 25 & $72(5)$ \\
6 & $\mathbf{7}$ & THF & 25 & n.r. \\
7 & $\mathbf{8}$ & THF & 25 & $65(<1)$ \\
8 & $\mathbf{9}$ & THF & 25 & $19(<1)$ \\
9 & $\mathbf{5}$ & Hexane & 0 & $28(4)$ \\
10 & $\mathbf{5}$ & Toluene & 0 & $20(4)$ \\
11 & $\mathbf{5}$ & Et $2 \mathrm{O}$ & 0 & $30(<1)$ \\
12 & $\mathbf{5}$ & DME & 0 & $38(2)$ \\
13 & $\mathbf{5}$ & $t$-BuOMe & 0 & $35(<1)$ \\
14 & $\mathbf{5}$ & $2-$ MeTHF & 0 & $70(5)$ \\
$15^{\mathrm{d}}$ & $\mathbf{5}$ & THF & -78 & $5(8)$ \\
\hline & $\mathbf{5}$ & THF & -78 & $25(7)$ \\
\hline
\end{tabular}


Table 1 (continued)

\begin{tabular}{ccccc}
\hline 16 & $\mathbf{6}$ & THF & 0 & $63(7)$ \\
17 & $\mathbf{6}$ & THF & -78 & $56(10)$ \\
18 & $\mathbf{6}$ & $2-\mathrm{MeTHF}$ & 0 & $65(8)$ \\
\hline
\end{tabular}

${ }^{\mathrm{a}}$ The reactions were carried out using 2-chloro-1-phenylpropane $2(0.5 \mathrm{mmol})$, lithium powder (1.5 mmol), arene 4-9 $(0.1 \mathrm{mmol})$, and pentan-3-one $(0.75 \mathrm{mmol}) .{ }^{\mathrm{b}}$ Yields were determined by ${ }^{1} \mathrm{H}$ NMR spectroscopy, and enantiomeric excess by chiral GLC (see experimental section). ${ }^{c}$ No reaction $=$ n.r. ${ }^{\mathrm{d}}$ Using $0.5 \mathrm{mmol}$ of BINOL.

Afterward, we turned our attention to the use of a binaphthyl derivative without any heteroatom in order to compare its activity and selectivity during the process with the catalysts 49. Accordingly, the use of 2,2'-dimethyl-1,1'-binaphthalene $\mathbf{1 1}$ was taken into consideration, and its synthesis was accomplished in two steps starting from BINOL. ${ }^{32,33}$ Compound $\mathbf{5}$ was transformed into the corresponding bistriflate 10, which was subsequently coupled with methylmagnesium bromide, in the presence of a nickel catalyst ( 7 mol\%), producing the expected 2,2'-dimethyl-1,1'-binaphthalene 11 (Scheme 3).<smiles>Oc1ccc2ccccc2c1-c1c(O)ccc2ccccc12</smiles>

$(S)-5$<smiles>CCOc1ccc2ccccc2c1-c1c(OCC)ccc2ccccc12</smiles>

$(S)-10$

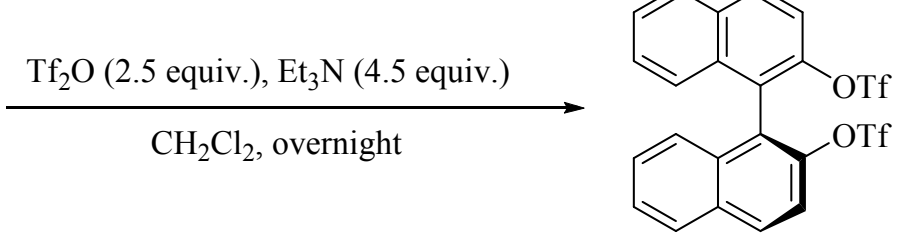

$(S)-10$

$(82 \%)$<smiles>Cc1ccc2ccccc2c1-c1c(C)ccc2ccccc12</smiles>

$(S)-11$

$(75 \%)$

Scheme 3. Synthesis of $(S)$-2,2'-dimethyl-1,1'-binaphthalene 11 from $(S)$-BINOL 5.

The lithiation reaction of 2-chloro-1-phenylpropane employing binaphthyl derivative $\mathbf{1 1}$ as electron carrier, in THF at room temperature, produced the corresponding organolithium intermediate which reacted with pentan-3-one, and after hydrolysis produced the alcohol $\mathbf{3}$ in 
$80 \%$ yield, with very poor enantioselectivity (Table 2 , entry 1 ). Lowering the temperature to $0{ }^{\circ} \mathrm{C}$ was detrimental to the activity of the catalyst, the final product being isolated in less than a half of the amount, and without a significant change in the selectivity (Table 2, entry 2). The use of other different symmetric ketones, such as cyclohexanone, heptan-3-one, nonan-5-one, dicyclopropyl ketone and dicyclohexyl ketone, produced after quenching the corresponding alcohols 12-16 with yields ranging from 46 to $70 \%$ (Table 2, entries 3, 5, 7, 9 and 10). The use of a more rigid ketone, i.e. cyclohexanone, produced the expected alcohol $\mathbf{1 2}$ in lower yield but higher enantioselectivity (Table 2, entry 3 ). As for pentan-3-one, reducing the temperature to 0 ${ }^{\circ} \mathrm{C}$ lowered the final yield but did not increase the enantioselectivity of the product (Table 2, entry 4). Interestingly, an increase of the length of the alkyl substituents in dialkyl ketones gave better selectivity in comparison with the use of pentan-3-one. Thus, alcohols $\mathbf{1 3}$ and $\mathbf{1 4}$ were obtained with higher enantioselectivities than alcohol 3 (Table 2, entries 5 and 7). For these two products, similar enantioselectivities were observed employing BINOL $\mathbf{6}$ as catalyst, although lower temperatures and longer reaction times were needed (Table 2, entries 6 and 8). Finally, the use of a ketone with bulkier substituents, such as dicyclopropyl ketone, produced the expected alcohol 16 with good yield, and an enantioselectivity of 50\% (Table 2, entry 10). As observed previously, the effect of the temperature was the same (the lower the temperature, the lesser activity), and without significant effect on the selectivity (Table 2, entry 11). For dicyclopropyl ketone, the use of BINOL as catalyst during the lithiation process, at $-78{ }^{\circ} \mathrm{C}$, produced the final product in less than $5 \%$ yield.

Table 2. Arene 6 and 11 catalyzed lithiation of 2-chloro-1-phenylpropane and reaction with different ketones. ${ }^{a}$

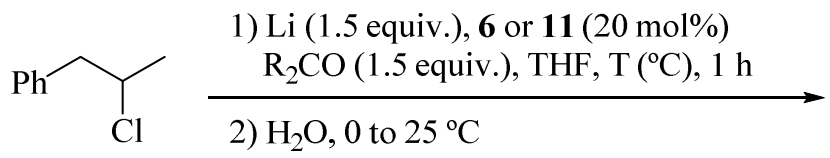

2

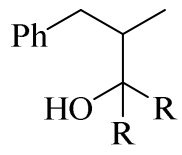

3, 12-16

\begin{tabular}{cccccc}
\hline Entry & Ketone & Arene & ${\mathrm{T}\left({ }^{\circ} \mathrm{C}\right)}$ & Product no. $^{\mathrm{b}}$ & Yield $^{\mathrm{c}}(\mathrm{ee} \%)^{\mathrm{d}}$ \\
\hline 1 & $\mathrm{Et}_{2} \mathrm{CO}$ & $\mathbf{1 1}$ & 25 & $\mathbf{3}$ & $80(5)$ \\
2 & $\mathrm{Et}_{2} \mathrm{CO}$ & $\mathbf{1 1}$ & 0 & $\mathbf{3}$ & $36(7)$ \\
3 & Cyclohexanone & $\mathbf{1 1}$ & 25 & $\mathbf{1 2}$ & $46(14)$ \\
4 & Cyclohexanone & $\mathbf{1 1}$ & 0 & $\mathbf{1 2}$ & $19(16)$ \\
5 & $(n-\mathrm{Pr})_{2} \mathrm{CO}$ & $\mathbf{1 1}$ & 25 & $\mathbf{1 3}$ & $51(10)$ \\
$6^{\mathrm{e}}$ & $(n-\mathrm{Pr})_{2} \mathrm{CO}$ & $\mathbf{6}$ & -78 & $\mathbf{1 3}$ & $49(12)$ \\
7 & $(n-\mathrm{Bu})_{2} \mathrm{CO}$ & $\mathbf{1 1}$ & 25 & $\mathbf{1 4}$ & $50(18)$ \\
$8^{\mathrm{e}}$ & $(n-\mathrm{Bu})_{2} \mathrm{CO}$ & $\mathbf{6}$ & -78 & $\mathbf{1 4}$ & $48(20)$ \\
\hline
\end{tabular}


Table 2 (continued)

\begin{tabular}{cccccc}
\hline 9 & $\left(c-\mathrm{C}_{6} \mathrm{H}_{11}\right)_{2} \mathrm{CO}$ & $\mathbf{1 1}$ & 25 & $\mathbf{1 5}$ & $63(5)$ \\
10 & $\left(c-\mathrm{C}_{3} \mathrm{H}_{5}\right)_{2} \mathrm{CO}$ & $\mathbf{1 1}$ & 25 & $\mathbf{1 6}$ & $70(50)$ \\
11 & $\left(c-\mathrm{C}_{3} \mathrm{H}_{5}\right)_{2} \mathrm{CO}$ & $\mathbf{1 1}$ & 0 & $\mathbf{1 6}$ & $19(55)$ \\
$12^{\mathrm{f}}$ & $\left(c-\mathrm{C}_{3} \mathrm{H}_{5}\right)_{2} \mathrm{CO}$ & $\mathbf{1 1}$ & 25 & $\mathbf{1 6}$ & $25(54)$ \\
\hline
\end{tabular}

${ }^{\mathrm{a}}$ The reactions were carried out using 2-chloro-1-phenylpropane 2 ( $\left.2 \mathrm{mmol}\right)$, lithium powder $(6 \mathrm{mmol})$, arene $(0.4 \mathrm{mmol})$, and ketone $(3 \mathrm{mmol}) .{ }^{\mathrm{b}}$ All products were $>95 \%$ pure (by GLC and/or $300-\mathrm{MHz}{ }^{1} \mathrm{H}$ NMR spectroscopy). ${ }^{\mathrm{C}}$ Isolated yield after column chromatorgraphy (silica gel, hexane/AcOEt mixtures) based on the starting compound 2. ${ }^{\mathrm{d}}$ Determined by chiral GLC or chiral HPLC (see experimental section). ${ }^{\mathrm{e}}$ Reaction time: 6 h. ${ }^{\mathrm{f}}$ Reaction time: $15 \mathrm{~min}$.

Regarding the mechanism of the reaction and taking into consideration that alcohol $\mathbf{1 6}$ was obtained in $70 \%$ yield with $50 \%$ of enantiomeric excess, it can be assumed that the reaction does not occur via a kinetic resolution of the racemic compound 2. Additionally, if the reaction with dicyclopropyl ketone was quenched after $15 \mathrm{~min}$. of reaction, the product was obtained in $25 \%$ yield with comparable enantiomeric excess (Table 2, entry 12), so enantiomeric excess does not decrease noticeably with reaction time as would be expected in a kinetic resolution. Furthermore, the structure of the ketone seems to influence in the selectivity of the process, so it should be considered that both steps: (i) the formation of the organolithium intermediate (by two electrontransfer processes from arene dianion $)^{28-30}$ and (ii) the subsequent nucleophilic addition to the ketone, occurs in close proximity to the chiral arene.

\section{Conclusions}

In conclusion, we have shown that different binaphthyl derivatives are effective catalysts in the arene-lithiation process of 2-chloro-1-phenylpropane 2. Among them, compounds 5 (BINOL), 6 (BINAP) and 11 (2,2'-dimethyl-1,1'-binaphthalene) are as active catalysts as DTBB, under similar reaction conditions. Additionally, the nucleophilic addition of the generated organolithium intermediate, employing catalyst 11, to different ketones allows the preparation of alcohols 3 and 12-16 in moderate to good yields, and with enantioselectivities up to $50 \%$. To the best of our knowledge, the results reported herein represent the first example of an enantioselective lithiation of a racemic chlorinated material. 


\section{Experimental Section}

General. All lithiation reactions were carried out under argon atmosphere in oven-dried glassware. All commercially available reagents (Aldrich and Alfa Aesar) were used without further purification, except in the case of liquid electrophiles, which were used freshly distilled. Biaryl compounds 4-8 were commercially purchased (Aldrich). Lithium powder was commercially available (Medalchemy, S. L.). Dry THF, toluene and dichloromethane were dried in a Sharlab PS-400-3MD solvent purification system using an alumina column. 2Methyltetrahydrofuran was commercially available (Pennakem), dried over Na. Other dry solvents were commercially available (Aldrich). Infrared analysis was performed with a FTIR Nicolet Impact 400D and a Jasco 4100LE (Pike MIRacle ATR) spectrophotometers, and wavenumbers are given in $\mathrm{cm}^{-1}$. NMR spectroscopic data were recorded with Bruker Avance 300 and 400 spectrometers (300 and $400 \mathrm{MHz}$ for ${ }^{1} \mathrm{H} \mathrm{NMR}, 75$ and $100 \mathrm{MHz}$ for ${ }^{13} \mathrm{C} \mathrm{NMR}$ ) using $\mathrm{CDCl}_{3}$ as the solvent and TMS as the internal standard. Chemical shifts are given in parts per million $(\delta)$, and coupling constants are given in Hertz $(J)$. Mass spectra (EI) were obtained at $70 \mathrm{eV}$ with an Agilent 5973 spectrometer, and fragment ions are given in $\mathrm{m} / \mathrm{z}$ with relative intensities (\%) in parenthesis, when indicated the samples were inserted in the modality of Direct Insertion Probe (DIP). High resolution mass spectra were acquired using a Bruker Esquire 3000+ ion-trap mass spectrometer (time-of-flight, micrOTOF-Q) with electrospray ionization (ESI). The purity of volatile compounds and the chromatographic analyses (GLC) were determined with an Agilent 6890N instrument equipped with a flame ionisation detector and a $30 \mathrm{~m}$ capillary column $(0.25 \mathrm{~mm}$ diameter, $0.25 \mu \mathrm{m}$ film thickness $)$, using nitrogen $(2 \mathrm{~mL} / \mathrm{min})$ as carrier gas, $\mathrm{T}_{\text {injector }}=275^{\circ} \mathrm{C}, \mathrm{T}_{\text {column }}=80^{\circ} \mathrm{C}(3 \mathrm{~min})$ and $80-270^{\circ} \mathrm{C}\left(15^{\circ} \mathrm{C} / \mathrm{min}\right)$; retention times $\left(\mathrm{t}_{\mathrm{r}}\right)$ are given in minutes under these conditions. Analytical TLC was performed on Merck aluminum sheets with silica gel 60 F254. Silica gel 60 (40-60 microns) was employed for chromatography. Optical rotations were measured on a Jasco P-1030 Polarimeter with a $5 \mathrm{~cm}$ cell ( $c$ given in $\mathrm{g} / 100 \mathrm{~mL}$ ). Enantioselectivities were determined by HPLC Jasco (LPU-2089 pump, MD-2010 Plus detector, and AS-2059 automatic injector) equipped with chiral columns (Chiralpak OD-H and Chiralpak IA) using mixtures of $n$-hexane/isopropanol as mobile phase, or GC analysis (Agilent technologies 7820A GC System) equipped with chiral columns (CP-Chiralsil-DEX CB) using $\mathrm{N}_{2}$ as a carrier gas.

Preparation of 2-chloro-1-phenylpropane (2). ${ }^{34}$ Thionyl chloride $(6.4 \mathrm{~mL}, 88 \mathrm{mmol})$ was slowly added, over $30 \mathrm{~min}$, to a solution of 1-phenylpropan-2-ol $(5.6 \mathrm{~mL}, 40 \mathrm{mmol})$ in $20 \mathrm{~mL}$ of dry dichloromethane, at $0{ }^{\circ} \mathrm{C}$ and under argon atmosphere. Next, the reaction mixture was stirred at room temperature during $72 \mathrm{~h}$. The resulting mixture was washed with a $\mathrm{NaHCO}_{3}$ solution $(10 \% \mathrm{w} / \mathrm{w}, 3 \times 5 \mathrm{~mL})$. The organic layer was dried with anhydrous $\mathrm{MgSO}_{4}$, and the solvents were evaporated in vacuo. The residue obtained was subjected to chromatography (silica gel, hexane) to yield the corresponding product $2(4.02 \mathrm{~g}, 65 \%)$ as colorless oil. $R_{\mathrm{f}}=0.46$ (hexane). $\mathrm{t}_{\mathrm{r}}=9.0$ min. ${ }^{1} \mathrm{H}$ NMR (300 MHz, $\left.\mathrm{CDCl}_{3}\right): \delta=1.52\left(3 \mathrm{H}, \mathrm{d}, J \quad 6.5,3 \times \mathrm{CH}_{3}\right), 2.96(1 \mathrm{H}, \mathrm{dd}, J$ 7.0, $13.8 \mathrm{~Hz}$, 
$\mathrm{PhCH} H), 3.09$ (1H, dd, J 7.0, $13.8 \mathrm{~Hz}, \mathrm{PhCHH}), 4.22(1 \mathrm{H}, \mathrm{m}, \mathrm{CHCl}), 7.20-7.32\left(5 \mathrm{H}, \mathrm{m}, \mathrm{C}_{6} \mathrm{H}_{5}\right)$.

${ }^{13} \mathrm{C}$ NMR $\left(75 \mathrm{MHz}, \mathrm{CDCl}_{3}\right): \delta=24.7,46.7,58.5,126.8,128.4,129.3,138.0$. IR (film): $v=$ 3086, 3063, $3028 \mathrm{~cm}^{-1}$. MS (EI): $m / z 156\left(\mathrm{M}^{+}+2,7 \%\right), 154\left(\mathrm{M}^{+}, 21\right), 91(100)$.

Preparation of $(\boldsymbol{R})-2,2$ '-bis(pyrrolidin-1-yl)-1,1'-binaphthalene $(9) .^{31}(+)-(R)-2.2$ '-Diamino1,1'-binaphthyl (286 mg, $1 \mathrm{mmol}$ ) was placed in a $50 \mathrm{~mL}$ round flask under argon, and toluene $(5 \mathrm{~mL})$ was added, stirring until complete solution. $N$-Ethyldiisopropylamine $(575 \mathrm{mg}, 4.4$ mmol) was added, followed by the addition of 1,4-dibromobutane (475 mg, $2.2 \mathrm{mmol}$ ). The reaction mixture was stirred under reflux conditions during $24 \mathrm{~h}$. Workup was performed by adding water $(35 \mathrm{~mL})$ to the reaction mixture. The organic layer was separated, the aqueous phase was extracted with toluene $(2 \times 30 \mathrm{~mL})$, and the combined organic layers were dried over anhydrous $\mathrm{MgSO}_{4}$. The solvents were evaporated in vacuo, and the residue obtained was recrystallized in $\mathrm{Et}_{2} \mathrm{O}$ affording pure product 9 as yellow solid $(176 \mathrm{mg}, 45 \%)$. $[\alpha]^{25}{ }_{\mathrm{D}}=-14(c$ 1.0, $\left.\mathrm{CHCl}_{3}\right)\left[\mathrm{lit}_{.} .^{31}[\alpha]^{20}{ }_{\mathrm{D}}=-1.55\left(\mathrm{c} 1.0, \mathrm{CHCl}_{3}\right)\right] . \mathrm{mp} 182-183{ }^{\circ} \mathrm{C}$ (AcOEt) (lit.: ${ }^{31} 182.5-183.5$ $\left.{ }^{\circ} \mathrm{C}\right) . R_{\mathrm{f}}=0.40$ (hexane). ${ }^{1} \mathrm{H} \mathrm{NMR}\left(300 \mathrm{MHz}, \mathrm{CDCl}_{3}\right): \delta=1.55-1.66,2.85-2.90,3.08-3.14(8 \mathrm{H}$, $\left.4 \mathrm{H}, 4 \mathrm{H}, 3 \mathrm{~m}, 8 \times \mathrm{CH}_{2}\right), 7.04-7.20,7.68-7.81(8 \mathrm{H}, 4 \mathrm{H}, 2 \mathrm{~m}, 12 \times \mathrm{ArH}) .{ }^{13} \mathrm{C} \mathrm{NMR}\left(75 \mathrm{MHz}, \mathrm{CDCl}_{3}\right)$ : $\delta=25.8,49.4,117.0,121.2,125.7,125.9,126.6,127.4,127.8,136.4,146.0$. IR (ATR): $v=$ 2963, 2862, $1377 \mathrm{~cm}^{-1}$. MS (DIP): $m / z 393\left(\mathrm{M}^{+}+1,17 \%\right), 392\left(\mathrm{M}^{+}, 56 \%\right), 338$ (16), 323 (11), 322 (17), 321 (39), 320 (100), 294 (12), 293 (14), 292 (11), 280 (22), 278 (15), 265 (13), 208 (11), $196(25), 139$ (16).

Preparation of $(\boldsymbol{S})$-2,2'-bis(trifluoromethanesulfonyloxy)-1,1'-binaphthalene (10). ${ }^{35,36}(S)$ [1,1'-binaphthalene]-2,2'-diol (2 g, $7 \mathrm{mmol})$ was placed in a $100 \mathrm{~mL}$ round flask under argon, and dry dichloromethane $(35 \mathrm{~mL})$ was added. Then, $\mathrm{Et}_{3} \mathrm{~N}(4.4 \mathrm{~mL}, 31.5 \mathrm{mmol})$ was added, and the reaction mixture was cooled to $0{ }^{\circ} \mathrm{C}$. Then, trifluoromethanesulfonic anhydride $(2.9 \mathrm{~mL}, 17.5$ mmol) was slowly added, and after the addition, the reaction mixture was allowed to warm to room temperature and stirred for further $12 \mathrm{~h}$. The reaction mixture was washed with water $(3 \times 5$ $\mathrm{mL}$ ), and the organic layer was dried over anhydrous $\mathrm{MgSO}_{4}$, and the solvents were evaporated in vacuo. The crude was subjected to chromatography (silica gel, hexane), yielding the compound 10 as a white solid $(3.15 \mathrm{~g}, 82 \%)$. $[\alpha]^{25}{ }_{\mathrm{D}}=+139\left(c 1.0, \mathrm{CHCl}_{3}\right)\left[\mathrm{lit}_{\mathrm{i}}:^{35}[\alpha]^{20}{ }_{\mathrm{D}}=+145\right.$ (c 1.0, $\left.\left.\mathrm{CHCl}_{3}\right)\right] . \mathrm{mp} 76-77^{\circ} \mathrm{C}$ (lit.: $\left.{ }^{35} 75-77^{\circ} \mathrm{C}\right) . R_{\mathrm{f}}=0.15$ (hexane). $\mathrm{t}_{\mathrm{r}}=18.3 \mathrm{~min} .{ }^{1} \mathrm{H} \mathrm{NMR}(300$ $\left.\mathrm{MHz}, \mathrm{CDCl}_{3}\right): \delta=7.26(2 \mathrm{H}, \mathrm{m}, 2 \times \mathrm{ArH}), 7.41(2 \mathrm{H}, \mathrm{m}, 2 \times \mathrm{ArH}), 7.58(2 \mathrm{H}, \mathrm{m}, 2 \times \mathrm{ArH}), 7.62(2 \mathrm{H}$, d, $J 9.0 \mathrm{~Hz}, 2 \times \mathrm{ArH}), 8.00(2 \mathrm{H}, \mathrm{d}, J 8.2 \mathrm{~Hz}, 2 \times \mathrm{ArH}), 8.14(2 \mathrm{H}, \mathrm{d}, J 9.1 \mathrm{~Hz}, 2 \times \mathrm{ArH}) .{ }^{13} \mathrm{C} \mathrm{NMR}$ $\left(75 \mathrm{MHz}, \mathrm{CDCl}_{3}\right): \delta=118.0\left(\mathrm{q}, J_{\mathrm{C}-\mathrm{F}}=320 \mathrm{~Hz}\right), 119.3,126.7,127.3,128.0,128.3,132.0,132.3$, 133.1, 145.3. IR (ATR): $v=1510,1422,1218,1136 \mathrm{~cm}^{-1} . \mathrm{MS}(\mathrm{EI}): \mathrm{m} / z 284\left[\mathrm{M}^{+}-2\left(\mathrm{SO}_{2} \mathrm{CF}_{3}\right)\right.$, 13\%], 268 (100), 255 (13), 226 (12).

Preparation of $\quad(S)-2,2$ '-dimethyl-1,1'-binaphthalene $\quad(11) .^{35,36} \quad(S)-2,2$ 'Bis(trifluoromethanesulfonyloxy)-1,1'-binaphthalene $\quad(\mathbf{1 0}, \quad 1 \quad \mathrm{~g}, \quad 1.8 \quad \mathrm{mmol})$ and bis(triphenylphosphine)-nickel(II) chloride $(84 \mathrm{mg}, 0.13 \mathrm{mmol}$ ) were placed in a $50 \mathrm{~mL}$ round- 


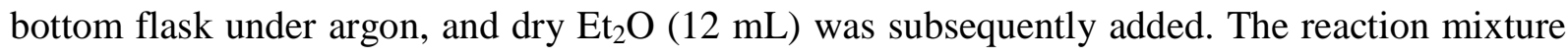
was cooled to $0{ }^{\circ} \mathrm{C}$ and $\mathrm{MeMgBr}$ (sol. $3 \mathrm{M}$ in $\mathrm{Et}_{2} \mathrm{O}, 2.7 \mathrm{~mL}, 8.1 \mathrm{mmol}$ ) was slowly added ( $\mathrm{ca} .30$ $\mathrm{min})$. After the addition, the resulting mixture was stirred at room temperature during $3 \mathrm{~h}$. Workup was performed by washing the reaction mixture with a $\mathrm{HCl}$ solution $(5 \% \mathrm{w} / \mathrm{w}, 3 \times 3 \mathrm{~mL})$ and with a brine solution $(3 \times 3 \mathrm{~mL})$. The organic layer was dried over anhydrous $\mathrm{MgSO}_{4}$, and the solvents were evaporated in vacuo. The residue obtained was subjected to chromatography (silica gel, hexane) yielding the product 11 as a white solid $(0.38 \mathrm{~g}, 75 \%)$. $[\alpha]^{25}{ }_{\mathrm{D}}=+36(c 1.0$, $\left.\mathrm{CHCl}_{3}\right)\left[\right.$ lit.: $\left.{ }^{35}[\alpha]^{20}{ }_{\mathrm{D}}=+38\left(c 1.0, \mathrm{CHCl}_{3}\right)\right] . \mathrm{mp} 69-72{ }^{\circ} \mathrm{C}$ (AcOEt) (lit. $\left..^{35} 72-74{ }^{\circ} \mathrm{C}\right) . R_{\mathrm{f}}=0.58$ (hexane). $\mathrm{t}_{\mathrm{r}}=17.9 \mathrm{~min} .{ }^{1} \mathrm{H} \mathrm{NMR}\left(300 \mathrm{MHz}, \mathrm{CDCl}_{3}\right): \delta=2.09\left(6 \mathrm{H}, \mathrm{s}, 2 \times \mathrm{CH}_{3}\right), 7.03(2 \mathrm{H}, \mathrm{d}, J 8.2$ $\mathrm{Hz}, 2 \times \mathrm{ArH}), 7.20(2 \mathrm{H}, \mathrm{m}, 2 \times \mathrm{ArH}), 7.39(2 \mathrm{H}, \mathrm{m}, 2 \times \mathrm{ArH}), 7.50(2 \mathrm{H}, \mathrm{d}, J 8.4 \mathrm{~Hz}, 2 \times \mathrm{ArH}), 7.88$ $(2 \mathrm{H}, \mathrm{m}, 2 \times \mathrm{ArH}) .{ }^{13} \mathrm{C} \mathrm{NMR}\left(75 \mathrm{MHz}, \mathrm{CDCl}_{3}\right): \delta=124.9,125.6,126.1,127.4,127.9,128.7$, 132.2, 132.7, 134.3, 135.1. IR (ATR): $v=3043,2247,1594,1506,1421,1352 \mathrm{~cm}^{-1}$. MS (IE): $m / z 282\left(\mathrm{M}^{+}, 100 \%\right), 267$ (41), 266 (19), 265 (30), 263 (12), 252 (28), 126 (12).

General procedure for the arene catalyzed lithiation of 2-chloro-1-phenylpropane and reaction with ketones. Preparation of alcohols 3, 12-16. To a $25 \mathrm{~mL}$ Schlenk flask were added lithium powder (42 mg, $6 \mathrm{mmol})$ and the arene $(0.4 \mathrm{mmol})$ in dry THF $(5 \mathrm{~mL})$. Then, 2-chloro-1phenylpropane $(2,0.31 \mathrm{~g}, 2 \mathrm{mmol})$ and pentan-3-one $(0.317 \mathrm{~mL}, 3 \mathrm{mmol})$ were added to the suspension, and the mixture was stirred for $1 \mathrm{~h}$ at room temperature. The flask was placed in an ice-water bath and $\mathrm{H}_{2} \mathrm{O}(5 \mathrm{ml})$ was added. The organic layer was separated, the aqueous phase was extracted with EtOAc $(3 \times 10 \mathrm{~mL})$, and the combined organic layers were dried over anhydrous $\mathrm{MgSO}_{4}$. The solvents were evaporated in vacuo, and the residue obtained was subjected to chromatography (silica gel, mixtures of hexane and ethyl acetate), giving the corresponding alcohols. Yields are given in Table 2. For physical, spectroscopic, and analytical data, as well as literature references of known compounds see below.

3-Ethyl-2-methyl-1-phenylpentan-2-ol (3). Colorless oil. $R_{\mathrm{f}}=0.31$ (hexane). $\mathrm{t}_{\mathrm{r}}=13.6 \mathrm{~min}$. ${ }^{1} \mathrm{H}$ $\operatorname{NMR}\left(300 \mathrm{MHz}, \mathrm{CDCl}_{3}\right): \delta=0.67\left(3 \mathrm{H}, \mathrm{d}, J 6.8 \mathrm{~Hz}, \mathrm{CHCH}_{3}\right), 0.82\left(3 \mathrm{H}, \mathrm{t}, J 7.5 \mathrm{~Hz}, \mathrm{CH}_{2} \mathrm{CH}_{3}\right)$, $0.83\left(3 \mathrm{H}, \mathrm{t}, J 7.5 \mathrm{~Hz}, \mathrm{CH}_{2} \mathrm{CH}_{3}\right), 1.24(1 \mathrm{H}$, br s, $\mathrm{OH}), 1.40-1.56\left(4 \mathrm{H}, \mathrm{m}, 2 \times \mathrm{CH}_{2} \mathrm{CH}_{3}\right), 1.76(1 \mathrm{H}$, m, $\left.\mathrm{CHCH}_{3}\right), 2.08(1 \mathrm{H}, \mathrm{dd}, J$ 11.4, $13.0 \mathrm{~Hz}, \mathrm{PhCH} H), 2.90(1 \mathrm{H}, \mathrm{dd}, J$ 2.4, $13.0 \mathrm{~Hz}, \mathrm{PhCHH})$, 7.06-7.09, 7.15-7.20 (3H, 2H, 2m, $\left.\mathrm{C}_{6} \mathrm{H}_{5}\right) .{ }^{13} \mathrm{C} \mathrm{NMR}\left(75 \mathrm{MHz}, \mathrm{CDCl}_{3}\right): \delta=7.4,7.5,13.0,27.9$, 28.0, 37.0, 41.5, 76.0, 125.5, 128.1, 129.1, 142.0. IR (film): $v=3485,3085,3061,3025 \mathrm{~cm}^{-1}$. MS (EI): m/z 188 (M+18, 14\%), 159 (17), 120 (14), 119 (12), 117 (12), 97 (29), 91 (100), 87 (87), 86 (12), 69 (15), 65 (11), 57 (11), 55 (25). HRMS (ESI, $m / z$ ): calcd for $\mathrm{C}_{14} \mathrm{H}_{22} \mathrm{NaO}$ $[\mathrm{M}+\mathrm{Na}]^{+} 229.1568$; found 229.1561 . Enantiomeric excess determination by chiral GC analysis, CP-Chirasil-DEX CB column, $\mathrm{T}=120^{\circ} \mathrm{C}, \mathrm{P}=14.3$ psi, retention times: $\mathrm{t}_{\mathrm{r}}=65.1$ min (major enantiomer) and 68.2 min.

1-(1-Methyl-2-phenylethyl)cyclohexanol (12). Colorless oil. $R_{\mathrm{f}}=0.26$ (hexane/AcOEt, 10:1). $\mathrm{t}_{\mathrm{r}}$ $=10.6$ min. ${ }^{1} \mathrm{H}$ NMR $\left(400 \mathrm{MHz}, \mathrm{CDCl}_{3}\right): \delta=0.80\left(3 \mathrm{H}, \mathrm{d}, J \quad 6.8 \mathrm{~Hz}, \mathrm{CHCH}_{3}\right), 1.20-1.32,1.49$ - 
$1.77\left(2 \mathrm{H}, 10 \mathrm{H}, 2 \mathrm{~m}, 5 \times \mathrm{CH}_{2}, \mathrm{CHCH}_{3}, \mathrm{OH}\right), 2.16(1 \mathrm{H}, \mathrm{dd}, J$ 11.2, $13.1 \mathrm{~Hz}, \mathrm{PhCH} H), 3.09$ (1H, dd, $J$ 2.8, $13.1 \mathrm{~Hz}, \mathrm{PhCHH}), 7.15-7.20,7.26-7.30\left(3 \mathrm{H}, 2 \mathrm{H}, 2 \mathrm{~m}, \mathrm{C}_{6} \mathrm{H}_{5}\right) .{ }^{13} \mathrm{C} \mathrm{NMR}\left(75 \mathrm{MHz}, \mathrm{CDCl}_{3}\right)$ : $\delta=13.1,21.9,22.0,25.9,33.7,34.9,37.0,45.5,73.4,125.6,128.2,129.2,142.2$. IR (film): $v=$ 3462, 3082, 3060, $3025 \mathrm{~cm}^{-1}$. MS (EI): $m / z, 200\left(\mathrm{M}^{+}-18,15 \%\right), 120$ (13), 99 (100), 98 (14), 91 (44), 81 (40). HRMS (ESI, $m / z$ ): calcd for $\mathrm{C}_{15} \mathrm{H}_{22} \mathrm{NaO}[\mathrm{M}+\mathrm{Na}]^{+} 241.1568$; found 241.1563 . Enantiomeric excess determination by chiral HPLC analysis, Chirapak OD-H column, hexane/ $i$ $\mathrm{PrOH}$ 95:5, flow rate $0.5 \mathrm{~mL} / \mathrm{min}, \lambda=215 \mathrm{~nm}$, retention times: $\mathrm{t}_{\mathrm{r}}=17.1 \mathrm{~min}$ (major enantiomer) and $25.3 \mathrm{~min}$.

4-(1-Methyl-2-phenylethyl)heptan-4-ol (13). ${ }^{37}$ Colorless oil. $R_{\mathrm{f}}=0.24$ (hexane/AcOEt, 10:1). $\mathrm{t}_{\mathrm{r}}$ $=10.3 \mathrm{~min} .{ }^{1} \mathrm{H} \mathrm{NMR}\left(400 \mathrm{MHz}, \mathrm{CDCl}_{3}\right): \delta=0.77\left(3 \mathrm{H}, \mathrm{d}, J 6.8 \mathrm{~Hz}, \mathrm{CHCH}_{3}\right), 0.95(3 \mathrm{H}, \mathrm{t}, J 7.2$ $\left.\mathrm{Hz}, \mathrm{CH}_{2} \mathrm{CH}_{3}\right), 0.96\left(3 \mathrm{H}, \mathrm{t}, J\right.$ 7.2 Hz, $\left.\mathrm{CH}_{2} \mathrm{CH}_{3}\right), 1.32-1.44,1.48-1.60\left(4 \mathrm{H}, 5 \mathrm{H}, 2 \mathrm{~m}, 2 \times \mathrm{CH}_{2} \mathrm{CH}_{2}\right.$, $\mathrm{OH}), 2.15-2.21\left(1 \mathrm{H}, \mathrm{m}, \mathrm{CHCH}_{3}\right), 2.18(1 \mathrm{H}, \mathrm{dd}, J$ 11.3, $13.1 \mathrm{~Hz}, \mathrm{PhCH} H), 3.01(1 \mathrm{H}, \mathrm{dd}, J$ 2.6, 13.1 y $2.6 \mathrm{~Hz}, \mathrm{PhCHH}), 7.15-7.19,7.25-7.29\left(3 \mathrm{H}, 2 \mathrm{H}, 2 \mathrm{~m}, \mathrm{C}_{6} \mathrm{H}_{5}\right) .{ }^{13} \mathrm{C} \mathrm{NMR}\left(100 \mathrm{MHz}, \mathrm{CDCl}_{3}\right)$ : $\delta=13.8,14.8,14.9,16.4,16.6,37.2,38.8,39.0,42.4,76.1,125.6,128.2,129.1,142.1$. IR (film): $v=3484,3084,3062,3024 \mathrm{~cm}^{-1}$. MS (EI): $\mathrm{m} / z 216\left(\mathrm{M}^{+}-18,4 \%\right), 191$ (27), 115 (100), 91 (72), 73 (10), 55 (18). Enantiomeric excess determination by chiral HPLC analysis, Chirapak OD-H column, hexane $/ i$-PrOH 95:5, flow rate $0.3 \mathrm{~mL} / \mathrm{min}, \lambda=215 \mathrm{~nm}$, retention times: $\mathrm{t}_{\mathrm{r}}=17.3 \mathrm{~min}$ (major enantiomer) and $26.2 \mathrm{~min}$.

5-(1-Methyl-2-phenylethyl)nonan-5-ol (14). ${ }^{38}$ Colorless oil. $R_{\mathrm{f}}=0.14$ (hexane/AcOEt, 20:1). $\mathrm{t}_{\mathrm{r}}$ $=10.9 \mathrm{~min} .{ }^{1} \mathrm{H} \mathrm{NMR}\left(400 \mathrm{MHz}, \mathrm{CDCl}_{3}\right): \delta=0.77\left(3 \mathrm{H}, \mathrm{d}, J 6.8 \mathrm{~Hz}, \mathrm{CHCH}_{3}\right), 0.93(3 \mathrm{H}, \mathrm{t}, J 6.8$ $\left.\mathrm{Hz}, \mathrm{CH}_{2} \mathrm{CH}_{3}\right), 0.94\left(3 \mathrm{H}, \mathrm{t}, J 6.8 \mathrm{~Hz}, \mathrm{CH}_{2} \mathrm{CH}_{3}\right), 1.18(1 \mathrm{H}, \mathrm{s}, \mathrm{OH}), 1.29-1.39,1.49-1.61(8 \mathrm{H}, 4 \mathrm{H}$, $\left.2 \mathrm{~m}, 2 \times \mathrm{CH}_{2} \mathrm{CH}_{2} \mathrm{CH}_{2}\right), 1.82-1.90\left(1 \mathrm{H}, \mathrm{m}, \mathrm{CHCH}_{3}\right), 2.18(1 \mathrm{H}, \mathrm{dd}, J 11.3,13.1 \mathrm{~Hz}, \mathrm{PhCH} H), 3.01$ $(1 \mathrm{H}, \mathrm{dd}, J$ 2.6, $13.1 \mathrm{~Hz}, \mathrm{PhCHH}), 7.16-7.20,7.25-7.29\left(3 \mathrm{H}, 2 \mathrm{H}, 2 \mathrm{~m}, \mathrm{C}_{6} \mathrm{H}_{5}\right) .{ }^{13} \mathrm{C} \mathrm{NMR}(100$ $\left.\mathrm{MHz}, \mathrm{CDCl}_{3}\right): \delta=13.2,14.2,23.4,23.5,25.4,25.5,36.1,36.3,42.4,76.1,125.6,128.2,129.2$, 142.2. IR (film): $v=3468,3082,3062,3029 \mathrm{~cm}^{-1}$. MS (EI): $m / z 244\left(\mathrm{M}^{+}-18,3 \%\right), 205$ (30), 144 (11), 143 (100), 91 (55), 69 (21). Enantiomeric excess determination by chiral HPLC analysis, Chirapak OD-H column, hexane $/ i$-PrOH 95:5, flow rate $0.3 \mathrm{~mL} / \mathrm{min}, \lambda=215 \mathrm{~nm}$, retention times: $t_{r}=16.4$ min (major enantiomer) and $22.4 \mathrm{~min}$.

1,1-Dicyclohexyl-2-methyl-3-phenylpropan-1-ol (15). Colorless oil. $R_{\mathrm{f}}=0.14$ (hexane/AcOEt, 25:1). $\mathrm{t}_{\mathrm{r}}=15.4$ min. ${ }^{1} \mathrm{H}$ NMR $\left(300 \mathrm{MHz}, \mathrm{CDCl}_{3}\right): \delta=0.83\left(3 \mathrm{H}, \mathrm{d}, J 6.6 \mathrm{~Hz}, \mathrm{CHCH}_{3}\right), 1.12-1.33$, 1.67-1.87 (11H, 12H, 2m, $\left.2 \times \mathrm{C}_{6} \mathrm{H}_{11}, \mathrm{OH}\right), 2.25,3.11\left(1 \mathrm{H}, 1 \mathrm{H}, 2 \mathrm{~m}, \mathrm{PhCH}_{2}\right), 7.15-7.19,7.25-7.30$ $\left(3 \mathrm{H}, 2 \mathrm{H}, 2 \mathrm{~m}, \mathrm{C}_{6} \mathrm{H}_{5}\right) .{ }^{13} \mathrm{C} \mathrm{NMR}\left(75 \mathrm{MHz}, \mathrm{CDCl}_{3}\right): \delta=14.6,26.6,26.7,27.4,28.4,28.5,28.6$, 38.4, 40.8, 44.2, 44.5, 78.1, 125.6, 128.2, 129.1, 142.6. IR (film): $v=3503,3081,3062,3028$ $\mathrm{cm}^{-1}$. MS (EI): $\mathrm{m} / z 232\left(\mathrm{M}^{+}+1-\mathrm{C}_{6} \mathrm{H}_{11}, 18 \%\right), 231\left(\mathrm{M}^{+}-\mathrm{C}_{6} \mathrm{H}_{11}, 97\right), 213$ (11), 196 (14), 195 (95), 119 (15), 111 (17), 91 (100), 83 (33), 81 (15), 55 (31). HRMS (ESI, $m / z$ ): calcd for $\mathrm{C}_{22} \mathrm{H}_{34} \mathrm{NaO}$ $[\mathrm{M}+\mathrm{Na}]^{+}$337.2507; found 337.2502. Enantiomeric excess determination by chiral HPLC 
analysis, Chirapak IA column, hexane $/ i$-PrOH 95:5, flow rate $0.5 \mathrm{~mL} / \mathrm{min}, \lambda=215 \mathrm{~nm}$, retention times: $t_{\mathrm{r}}=13.3 \mathrm{~min}$ and $15.2 \mathrm{~min}$ (major enantiomer).

1,1-Dicyclopropyl-2-methyl-3-phenylpropan-1-ol $\quad$ (16). Colorless $\quad$ oil. $\quad R_{\mathrm{f}}=0.12$ (hexane/AcOEt, 30:1). $\mathrm{t}_{\mathrm{r}}=10.7 \mathrm{~min} .{ }^{1} \mathrm{H} \mathrm{NMR}\left(300 \mathrm{MHz}, \mathrm{CDCl}_{3}\right): \delta=0.26-0.37,0.36-0.50$, 0.84-0.89 (2H, 6H, 3H, 3m, $\left.2 \times \mathrm{C}_{3} \mathrm{H}_{5}, \mathrm{OH}\right), 0.93\left(3 \mathrm{H}, \mathrm{d}, J \quad 6.7 \mathrm{~Hz}, \mathrm{CHCH}_{3}\right), 1.88-1.91(1 \mathrm{H}, \mathrm{m}$, $\left.\mathrm{CHCH}_{3}\right), 2.32(1 \mathrm{H}, \mathrm{dd}, J$ 11.4, $13.0 \mathrm{~Hz}, \mathrm{PhCH} H), 3.26(1 \mathrm{H}, \mathrm{dd}, J$ 2.80, $13.0 \mathrm{~Hz}, \mathrm{PhCHH}), 7.15-$ 7.21, 7.26-7.31 (3H y $\left.2 \mathrm{H}, 2 \mathrm{~m}, \mathrm{C}_{6} \mathrm{H}_{5}\right) .{ }^{13} \mathrm{C} \mathrm{NMR}\left(75 \mathrm{MHz}, \mathrm{CDCl}_{3}\right): \delta=-1.1,1.0,1.2,1.4$ $\left(2 \mathrm{xCOHCHCH}_{2} \mathrm{CH}_{2}\right), 14.1,15.8,16.7,47.6,38.1,72.6,125.5,128.1,129.2,142.3$. IR (film): v $=3502,3082,3062,3028 \mathrm{~cm}^{-1}$. MS (EI): $\mathrm{m} / z 189\left(\mathrm{M}^{+}-\mathrm{C}_{3} \mathrm{H}_{5}, 3 \%\right), 112$ (13), 111 (100), 91 (43), 69 (72). HRMS (ESI, $m / z$ ): calcd for $\mathrm{C}_{16} \mathrm{H}_{22} \mathrm{NaO}[\mathrm{M}+\mathrm{Na}]^{+}$253.1568; found 253.1563. Enantiomeric excess determination by chiral GC analysis, CP-Chirasil-DEX CB column, $\mathrm{T}=$ $150{ }^{\circ} \mathrm{C}, \mathrm{P}=14.3$ psi, retention times: $\mathrm{t}_{\mathrm{r}}=37.2$ (major enantiomer) min and $38.5 \mathrm{~min}$.

\section{Acknowledgements}

Financial support from the Ministerio de Ciencia e Innovación (MICINN) of Spain (Project Nos. CTQ2007-65218, CTQ2011-24165, Consolider Ingenio 2010 CSD2007-00006), the Generalitat Valenciana (PROMETEO/2009/0349 and FEDER), and the Universidad de Alicante is acknowledged. We also thank Medalchemy S. L. and Chemetall GmbH for a gift of chemicals, especially lithium powder, and Professor Pedro Merino for the HRMS measurements.

\section{References}

1. Boudier, A.; Bromm, L. O.; Lotz, M.; Knochel, P. Angew. Chem. Int. Ed. 2000, 39, 4414. http://dx.doi.org/10.1002/1521-3773(20001215)39:24<4414::AID-ANIE4414>3.0.CO;2-C

2. Knochel, P.; Hupe, E.; Dohle, W.; Lindsay, D. M.; Bonnet, V.; Queguiner, G.; Boudier, A.; Kopp, F.; Demay, S.; Seidel, N.; Calaza, M. I.; Vu, V. A.; Sapountzis, I.; Bunlaksananusorn, T. Pure Appl. Chem. 2002, 74, 11. http://dx.doi.org/10.1351/pac200274010011

3. Yus, M.; Foubelo, F. In Handbook of Functionalized Organometallics; Knochel, P. Ed.; Wiley-VCH: Weinheim, 2005.

4. Nájera, C.; Yus, M. Trends Org. Chem. 1991, 2, 155.

5. Nájera, C.; Yus, M. Org. Prep. Proc. Int. 1995, 27, 383. http://dx.doi.org/10.1080/00304949509458476

6. Nájera, C.; Yus, M. Recent Res. Devel. Org. Chem. 1997, 1, 67.

7. Yus, M.; Foubelo, F. Rev. Heteroatom. Chem. 1997, 17, 73.

8. Foubelo, F.; Yus, M. Trends Org. Chem. 1998, 7, 1. 
9. Alonso, F.; Meléndez, J.; Yus, M. Russ. Chem. Bull. 2003, 52, 2628.

http://dx.doi.org/10.1023/B:RUCB.0000019879.74515.27

10. Nájera, C.; Sansano, J. M.; Yus, M. Tetrahedron 2003, 59, 9255.

http://dx.doi.org/10.1016/j.tet.2003.09.065

11. Nájera, C.; Yus, M. Curr. Org. Chem. 2003, 7, 867.

http://dx.doi.org/10.2174/1385272033486675

12. Chinchilla, R.; Nájera, C.; Yus, M. Chem. Rev. 2004, 104, 2667.

http://dx.doi.org/10.1021/cr020101a

PMid:15137804

13. Chinchilla, R.; Najera, C.; Yus, M. Tetrahedron 2005, 61, 3139.

http://dx.doi.org/10.1016/j.tet.2004.08.011

14. Foubelo, F.; Yus, M. Curr. Org. Chem. 2005, 9, 459.

http://dx.doi.org/10.2174/1385272053174921

15. Foubelo, F.; Yus, M. Chem. Soc. Rev. 2008, 37, 2620.

http://dx.doi.org/10.1039/b803415j

PMid:19020676

16. Guijarro, D.; Yus, M. Recent Res. Dev. Org. Chem. 1998, 2, 713.

17. Guijarro, D.; Pastor, I. M.; Yus, M. Curr. Org. Chem. 2011, 15, 375.

http://dx.doi.org/10.2174/138527211794072560

18. Guijarro, D.; Pastor, I. M.; Yus, M. Curr. Org. Chem. 2011, 15, 2362.

http://dx.doi.org/10.2174/138527211796150589

19. Yus, M. Chem. Soc. Rev. 1996, 25, 155.

http://dx.doi.org/10.1039/cs9962500155

20. Ramón, D. J.; Yus, M. Eur. J. Org. Chem. 2000, 225.

http://dx.doi.org/10.1002/(SICI)1099-0690(200001)2000:2<225::AID-EJOC225>3.0.CO;2-

$\underline{\mathrm{A}}$

21. Yus, M. Synlett 2001, 1197.

http://dx.doi.org/10.1055/s-2001-16031

22. Yus, M. Pure Appl. Chem. 2003, 75, 1453.

http://dx.doi.org/10.1351/pac200375101453

23. Yus, M. In The Chemistry of Organolithium Compounds; Rappoport, Z.; Mareck, I. Eds.; J. Wiley \& Sons: Chichester, 2004; p. Chapter 11.

24. Guijarro, A.; Gómez, C.; Yus, M. Trends Org. Chem. 2001, 8, 65.

25. Alonso, F.; Radivoy, G.; Yus, M. Russ. Chem. Bull. 2003, 52, 2563.

http://dx.doi.org/10.1023/B:RUCB.0000019874.01782.b4

26. Alonso, F.; Yus, M. Chem. Soc. Rev. 2004, 33, 284.

http://dx.doi.org/10.1039/b315131j

PMid:15272368 
27. Alonso, F.; Riente, P.; Yus, M. Acc. Chem. Res. 2011, 44, 379.

http://dx.doi.org/10.1021/ar1001582

PMid:21417317

28. Yus, M.; Herrera, R. P.; Guijarro, A. Tetrahedron Lett. 1999, 42, 3455.

http://dx.doi.org/10.1016/S0040-4039(01)00512-3

29. Yus, M.; Herrera, R. P.; Guijarro, A. Chem. Eur. J. 2002, 8, 2574.

http://dx.doi.org/10.1002/1521-3765(20020603)8:11<2574::AID-CHEM2574>3.0.CO;2-K

30. De la Viuda, M.; Yus, M.; Guijarro, A. J. Phys. Chem. B 2011, 115, 14610.

http://dx.doi.org/10.1021/jp2074573

PMid:22034859

31. Johansson, M. J.; Schwartz, L.; Amedjkouh, M.; Kann, N. Tetrahedron: Asymmetry 2004, 15,3531 .

http://dx.doi.org/10.1016/j.tetasy.2004.09.023

32. Page, P. C. B.; Farah, M. M.; Buckley, B. R.; Blacker, A. J. J. Org. Chem. 2007, 72, 4424.

http://dx.doi.org/10.1021/jo070255w

PMid:17506579

33. Nareddy, P.; Mantilli, L.; Guénée, L.; Mazet, C. Angew. Chem. Int. Ed. 2012, 51, 3826.

http://dx.doi.org/10.1002/anie.201108061

PMid:22389114

34. Cahiez, G.; Lefèvre, N.; Poizat, M.; Moyeux, A. Synthesis 2013, 45, 231.

http://dx.doi.org/10.1055/s-0032-1317927

35. Page, P. C. B.; Buckley, B. R.; Farah, M. M.; Blacker, A. J. Eur. J. Org. Chem. 2009, 3413. http://dx.doi.org/10.1002/ejoc.200900252

36. Wöste, T. H.; Oestreich, M. Chem. Eur. J. 2011, 17, 11914.

http://dx.doi.org/10.1002/chem.201101695

PMid:21898621

37. Yus, M.; Martínez, P.; Guijarro, D. Tetrahedron 2001, 57, 10119.

http://dx.doi.org/10.1016/S0040-4020(01)01063-8

38. Drewes, S. E.; Malissar, D. G. S.; Roos, G. H. P. Chem. Ber. 1993, 126, 2663.

http://dx.doi.org/10.1002/cber.19931261216 